\title{
Role of global longitudinal strain diastolic index in assessment of patients with suspected obstructive coronary artery disease and normal or mildly reduced ejection fraction
}

\author{
Mihaela Bolog', Mihaela Dumitrescu', Florentina Romanoschi', Elena Pacuraru', Alina Rapa'
}

\begin{abstract}
Objective - To examine the utility of global longitudinal strain imaging diastolic index (SI-DI) in the assessment of patients with suspected obstructive coronary artery disease (CAD). Methods - We performed rest $2 \mathrm{D}$ standard echocardiography and strain imaging in 30 healthy subjects and in 148 patients with normal or mildly reduced ejection fraction and indication for coronarography for suspected obstructive CAD. Standard echocardiographic and strain parameters were analysed. Results - Global SI-DI was significantly lower in the selected vs control group ( $p<0.00 \mathrm{I})$. After coronarography patients were divided in three subgroups: 74 patients with more than 50\% obstruction in any major artery, 26 patients with previous revascularisation but no significant obstructive lesions at present and 48 patients without obstructive artery disease. Average global SI- DI was significantly lower in the subgroup with obstructive CAD vs the other two subgroups $(p<0.05)$. Global SI-DI lower than 0.5 had a good sensitivity $(84 \%)$ and a reasonable positive predictive value $(52 \%)$ for detection of obstructive CAD. Conclusions - Global SI-DI is significantly lower in patients with obstructive CAD and normal or mildly reduced ejection fraction compared with normal subjects. A cut off value lower than 0.5 selects patients with a higher probability of obstructive CAD.
\end{abstract}

Keywords: strain imaging, coronary artery disease.

Rezumat: Obiectivul studiului - Este de a examina utilitatea indicelui diastolic global longitudinal(SI-DI ) evaluat prin ecocardiografie 2D metoda speckle tracking în evaluarea pacienților cu risc de boală coronariană obstructivă (CAD). Metoda - 30 de subiecți sănătoși și I 48 de pacienți cu suspiciunea de CAD cu indicație pentru coronarografie au fost examinați ecocardiografic bidimensional standard și speckle tracking. Rezultat - SI-DI global a fost semnificativ mai mic la pacienții cu suspiciunea de CAD vs grup de control $(\mathrm{p}<0.00 \mathrm{I})$. După coronarografie pacienții au fost împărțiți în trei subgrupe: 74 de pacienți cu mai mult de $50 \%$ obstrucție coronariană, 26 de pacienți cu revascularizare anterioară, dar fără leziuni obstructive semnificative în prezent și 48 pacienți fară leziuni. Valoarea medie a SI-DI global a fost semnificativ mai mică în subgrupul pacienților cu leziuni obstructive vs celelalte două subgrupe $(p<0,05)$. SI-DI global mai mic de 0,5 a avut o sensibilitate de $84 \%$ și o valoarea predictivă pozitivă de $52 \%$ pentru detectare CAD. Concluzii - SI-DI global este semnificativ mai mic la pacienții cu leziuni coronariene obstructive și fracția de ejecție normală sau ușor redusă în comparație cu subiecții normali. O valoare mică decât 0,5 selectează pacienții cu o probabilitate mai mare de CAD.

Cuvinte cheie: imagistica de strain, boală coronariană obstructivă.

\section{INTRODUCTION}

Strain is a measurement of dimensional change or deformation. Imaging techniques have been developed to quantify myocardial strain in clinical practice'. The most widely used is speckle tracking echocardiography which has been proved to have an important role in evaluation of subtle left ventricular systolic disfunction in va-

' „Prof. Dr. Agrippa lonescu” Emergency Clinical Hospital, Bucharest, Romania rious clinical conditions (assessment of cardiotoxicity, valvular disease, left ventricular hypertrophy, ischemic heart disease). Different strain patterns could orient the diagnostic (amyloidosis, pathologic hypertrophy, regional disfunction). The role of systolic and/or diastolic strain analysis in regional wall motion abnormalities in ischemic heart disease was validated in previous

\section{Contact address:}

Mihaela Bolog, MD, Department of Internal Medicine and Cardiology, „Prof. Dr. Agrippa lonescu” Emergency Clinical Hospital, Bucharest, Romania.

E-mail: mihaela.bolog@gmail.com 
studies $^{2-5}$. Post-systolic shortening by speckle tracking echocardiography is an independent predictor of cardiovascular events ${ }^{6}$ and post-systolic strain index, a quantitative measurement of post systolic shortening, is a parameter that can identify ischemic segments ${ }^{7}$. There have been proposed several mechanisms for ischemia- related diastolic abnormalities: reduced systolic contraction followed by decreased elastic recoil and subsequently decreased early diastolic untwisting and ventricular suction, reduced chamber compliance by fibrotic changes, delayed active contraction or late passive myocardial contraction (post-systolic thickening) ${ }^{8,9}$. Diastole is also an active process, energy - dependent directly affected by hypoxemia. Ischemia - induced delay in regional relaxation (stunned regional diastolic dysfunction) in the perfusion territory of the involved coronary artery was demonstrated in previous studies. Ishii ${ }^{10}$ demonstrated that impaired diastolic function with delayed outward wall motion persisted beyond recovery after ischemia. Quantitative analysis of regional diastolic dysfunction can be obtained by several echocardiographic methods like color kinesis, tissue doppler imaging and by speckle tracking strain imaging. Several studies demonstrated previously that analysis of diastolic images by color kinesis offers a quantitative evaluation of global diastolic function. $\mathrm{Ha}-$ rada" defined a color kinesis diastolic index (CK-DI) as the degree of left ventricular segmental expansion during the first $30 \%$ of diastole and proved that it corelates with standard diastolic parameters. The idea of using one third of diastole comes from a previous study which reported that peak filling rate during the first third of diastole were significantly lower at rest in patients with coronary artery disease than in normal patients, despite similar heart rates ${ }^{12}$.Validated tissue doppler imaging (TDI) parameters of left ventricular filling pressure (E/E') are indirect measures of ventricular filling method is angle dependent, influenced by preload and has a relatively broad "grey zone". Strain imaging is less influenced by these factors and offers both regional and global characterisation of myocardial deformation. Strain imaging diastolic index was reported to be a sensitive marker to detect LV regional delayed relaxation during early diastole in myocardial ischemia induced by exercise ${ }^{8}$ and it proved to be associated with severe coronary artery stenosis ${ }^{13}$. Rest global longitudinal SI-DI was shown to correlate with left ventricular (LV) filling pressures in suspected coronary artery disease ${ }^{14}$ and with NTproBNP in hypertensive patients ${ }^{15}$. However, usefulness of global SI-DI in the assessment of patients with suspected CAD must be established.

\section{METHODS}

We performed 2 D standard echocardiography and strain imaging in 30 healthy subjects and in 148 patients with suspected obstructive CAD, normal or borderline ejection fraction (EF) and indication for coronarography. Criteria for referral to coronary arteriography are presented in Table I. Patients with severe or rest symptoms, severe valvulopathy, arrythmia and/ or EF less than $45 \%$ were excluded. Standard echocardiographic parameters left ventricular global longitudinal strain (LVGLS) and global SI-DI were analysed. The patients subsequently underwent coronary angiographic examination.

After coronarography patients were divided in three subgroups: 74 patients (50\%) had more that $50 \%$ coronary obstruction in any major artery, 26 patients (17.5\%) had previous revascularisation but no significant obstructive lesions at present and 48 patients (32.5\%) were without obstructive artery disease. General and echocardiographic characteristics in controIs and selected patients before and after coronary angiographic examination are presented in Table 2 and 3.

\section{Standard two-dimensional echocardiography}

Transthoracic echocardiography was performed using bidimensional, M-mode, pulse wave Doppler, colorflow Doppler, tissue doppler and speckle tracking imaging with an ultrasound system Philipps Epiq 7G. Images were acquired and analyzed according to current recomandations ${ }^{16}$. Atrial and ventricular dimensions were measured, ejection fraction was calculated with Simpson method, diastolic dysfunction indices according to recommendations ${ }^{17}$. The left ventricular mass

\begin{tabular}{|l|l|}
\hline Table I. Clinical and/or imagistic criteria for referral to coronarography & Number of patients \\
\hline Indication for coronary angiography & 59 \\
\hline Positive ecg stress test, high risk for cardiac heart disease & 28 \\
\hline Symptoms, high risk for cardiac heart disease, uninterpretable ecg stress test & 25 \\
\hline Symptoms, high risk for cardiac heart disease, unable to exercise & 36 \\
\hline Suspected obstructive coronary artery disease at coronary CT angiography & \\
\hline
\end{tabular}




\begin{tabular}{|c|c|c|c|}
\hline Variables & $\begin{array}{c}\text { Controls } \\
\mathbf{N}=30\end{array}$ & $\begin{array}{c}\text { Suspected obstructive } \\
\text { CAD } \\
N=148\end{array}$ & $p$ value \\
\hline \multicolumn{4}{|l|}{ Baseline characteristics } \\
\hline Age(years) & $41.2 \pm 9.8$ & $62 \pm 11.2$ & $P<0.00$ I \\
\hline Women/men & $10 / 20$ & $55 / 93$ & NS \\
\hline Hypertension & - & 108 & - \\
\hline Diabetes mellitus & - & 47 & - \\
\hline Previous revascularisation & - & 26 & - \\
\hline \multicolumn{4}{|l|}{ Medication } \\
\hline Beta-blokers & - & 89 & - \\
\hline Nitrates & - & 115 & - \\
\hline ACE or ARB inhibitors & - & 97 & - \\
\hline Calcium Channel blockers & - & 66 & - \\
\hline Diuretics & - & 52 & - \\
\hline Antiplatelets & - & 132 & - \\
\hline Statins & & 96 & \\
\hline \multicolumn{4}{|l|}{ Echocardiographic data } \\
\hline LVEF (\%) & $59.3 \pm 4.3$ & $51.9 \pm 8.2$ & $p<0.001$ \\
\hline LVGLS(\%) & $-22.3 \pm 3.1$ & $-19.4 \pm 4.1$ & $P<0.001$ \\
\hline LV mass index $(\mathrm{g} / \mathrm{m} 2)$ & $98 \pm 7.3$ & $119 \pm 8.1$ & $P<0.001$ \\
\hline LAVI (ml/m2) & $21 \pm 5.4$ & $29 \pm 7.8$ & $\mathrm{P}<0.05$ \\
\hline Mitral E/A ratio & $1.3 \pm 0.5$ & $0.8 \pm 0.4$ & $\mathrm{P}<0.05$ \\
\hline $\mathrm{e}^{\prime}(\mathrm{cm} / \mathrm{s})$ & $10.1 \pm 2.4$ & $7.4 \pm 2.9$ & $\mathrm{P}<0.05$ \\
\hline$E / e^{\prime}$ & $6.9 \pm 2.1$ & $11.3 \pm 3.5$ & $P<0.001$ \\
\hline No diastolic disfunction (DD) & 30 & 8 & \\
\hline Grade I DD & - & 57 & - \\
\hline Grade II DD & - & 59 & - \\
\hline Grade III DD & - & 24 & - \\
\hline SIDI(\%) & $69 \pm 8$ & $4 I \pm I I$ & $P<0.001$ \\
\hline
\end{tabular}

was calculated with Devereux formula. Atrial volume has been indexed to the body surface area. Pulsedwave Doppler imaging was used to measure mitral valve inflow velocity peak at early $(E)$ and late diastole (A) in a standard manner.

Tissue Doppler imaging of the left ventricular longitudinal function was used to determine mitral annular velocities in early (e') diastole at both septal ( $e^{\prime}$ septal) and lateral (e' lateral) annulus. For each examination E/e' and average $\mathrm{e}^{\prime}\left(\mathrm{e}^{\prime}\right.$ septal $+\mathrm{e}^{\prime}$ lateral /2) were calculated.

\section{Speckle tracking two-dimensional echocardiography}

Echocardiographic images for speckle tracking analysis were acquired in 2-,3-, and 4- chamber views at a high frame rate (60-80 frames/s). Images were obtained during a transient breath hold and stored for offline analysis. Left ventricular global longitudinal strain was measured using the commercial available software, on PC workstation (QLAB,7.0). End diastole was defined as the time of R-wave peak and end systole as time of aortic closure, which was defined automatically on 2-D echography. After initialization of strain measurement, the computer automatically defined the region of interest (ROI), which was manual adjusted, when necessary. There were recorded I-3 stable consecutive cardiac cycles for each view. Atrial and ventricular premature beats were excluded. Strain was measured automatically in each segment for each view and subsequently accepted by the person who performed the analysis. Peak strain was defined as the highest strain value that was acquired in the longitudinal direction through the cardiac cycle. Global longitudinal strain and peak strain for each segment were displayed in "bull's eye" view. Strain curves were displayed for each segment in all cardiac cycle. Average end -systolic strain for each view was measured at the closure of aortic valve, displayed on strain curves graphic (Figure I). Global SI-DI was determined as end-systolic strain (a) minus strain at I/3 of diastole (b) (measured on strain curves graphic using the linear markers), reported on end-systolic strain (a). The formula used for 


\begin{tabular}{|c|c|c|c|c|}
\hline Variables & $\begin{array}{c}\text { Obstructive CAD } \\
\qquad \begin{array}{c}\mathbf{N}=74 \\
\end{array}\end{array}$ & $\begin{array}{c}\text { Non obstructive } \\
\text { CAD } \\
\mathbf{N}=\mathbf{2 6}\end{array}$ & $\begin{array}{c}\text { No CAD } \\
N=48\end{array}$ & p-value \\
\hline \multicolumn{5}{|l|}{ Baseline characteristics } \\
\hline Age(years) & $61 \pm 11.2$ & $63 \pm 9.7$ & $58 \pm 9.8$ & NS \\
\hline Women/men & $30 / 44$ & $7 / 19$ & $18 / 30$ & \\
\hline Hypertension & 50 & 19 & 39 & NS \\
\hline Diabetes mellitus & 28 & 8 & 11 & NS \\
\hline Previous revascularisation & - & 26 & - & - \\
\hline \multicolumn{5}{|l|}{ Medication } \\
\hline Beta-blokers & 56 & 13 & 20 & NS \\
\hline Nitrates & 63 & 19 & 33 & NS \\
\hline ACE or ARB inhibitors & 49 & 18 & 30 & NS \\
\hline Calcium Channel blockers & 34 & 11 & 21 & NS \\
\hline Diuretics & 28 & 9 & 15 & NS \\
\hline Antiplatelets & 72 & 20 & 40 & NS \\
\hline Statins & 34 & 30 & 32 & NS \\
\hline \multicolumn{5}{|l|}{ Echocardiographic data } \\
\hline LVEF (\%) & $50.1 \pm 8.1$ & $48.5 \pm 7.2$ & $54.1 \pm 7.9$ & NS \\
\hline LVGLS(\%) & $-16.4 \pm 4.9$ & $-18.2 \pm 3.9$ & $-21 \pm 4.2$ & $\mathrm{p}<0.05$ \\
\hline LV mass index $(\mathrm{g} / \mathrm{m} 2)$ & $122 \pm 8.9$ & $118 \pm 7.8$ & $115 \pm 7.3$ & NS \\
\hline LAVI (ml/m2) & $30 \pm 8.9$ & $28 \pm 6.9$ & $27 \pm 6.5$ & $\mathrm{p}<0.05$ \\
\hline Mitral E/A ratio & $0.7 \pm 0.4$ & $0.8 \pm 0.3$ & $0.8 \pm 0.4$ & NS \\
\hline $\mathrm{e}^{\prime}(\mathrm{cm} / \mathrm{s})$ & $7.1 \pm 3.2$ & $7.8 \pm 2.5$ & $8.3 \pm 3.1$ & $p<0.05$ \\
\hline$E / e^{\prime}$ & $12.7 \pm 4.2$ & $10.1 \pm 3.9$ & $9.1 \pm 3.2$ & $P<0.05$ \\
\hline No diastolic disfunction (DD) & 2 & $\mathrm{I}$ & 5 & \\
\hline Grade I DD & 10 & 12 & 35 & $P<0.05$ \\
\hline Grade II DD & 43 & 9 & 7 & $\mathrm{P}<0.05$ \\
\hline Grade III DD & 19 & 4 & I & $P<0.05$ \\
\hline SIDI(\%) & $32 \pm 12$ & $41 \pm 9$ & $46 \pm 11$ & $\mathrm{P}<0.05$ \\
\hline
\end{tabular}

global SI-DI calculation was (a-b)/a. Global longitudinal SI-DI was calculated as the average of global SI-DI obtained from the 3 apical views ${ }^{9-11}$.

\section{Statistical analysis}

The obtained data were expressed as mean values \pm standard deviations. The relationship between the continuous variables was calculated using Pearson's correlation coefficient. Comparison between means of two groups with continuous variables was performed using Student's $t$-test and for categorical variables using $\chi^{2}$ and between several groups using ANOVA analysis. Univariable and multivariable Cox proportional hazards models were used to calculate hazard ratios (HR). Analysis was performed using SPSS version 17 for Windows. A $p$ value $<0.5$ was considered significant.

\section{RESULTS}

General and echocardiographic data are presented in Table 2. Of the I 48 patients selected 55 were women, mean age was $62 \pm 11$ years old, 108 were hypertensive, 47 had diabetes mellitus and 26 were previously revascularized. Selected patients had cardiovascular risk factors and at least one episode of angina or angina equivalent in their medical history (not in the last month). All patients were under treatment, class of medication being mentioned in Table 2. At the enrolment patients had mild or no symptoms. Healthy subjects were significantly younger (4I.2 29.8 years old) and had normal echocardiographic examination. Mean EF in studied group, although in normal range was significantly lower than in control group (5I\% vs $59 \%$ respectively, $\mathrm{p}<0.00 \mathrm{I}$ ).

\section{Coronary angiography data}

Elective coronarography was performed in all selected patients. Indications for coronarography are presented in Table I. After coronarography patients were divided in three subgroups: 74 patients (50\%) had more that $50 \%$ coronary obstruction in any major artery, 26 patients (17.5\%) had previous revascularisation 


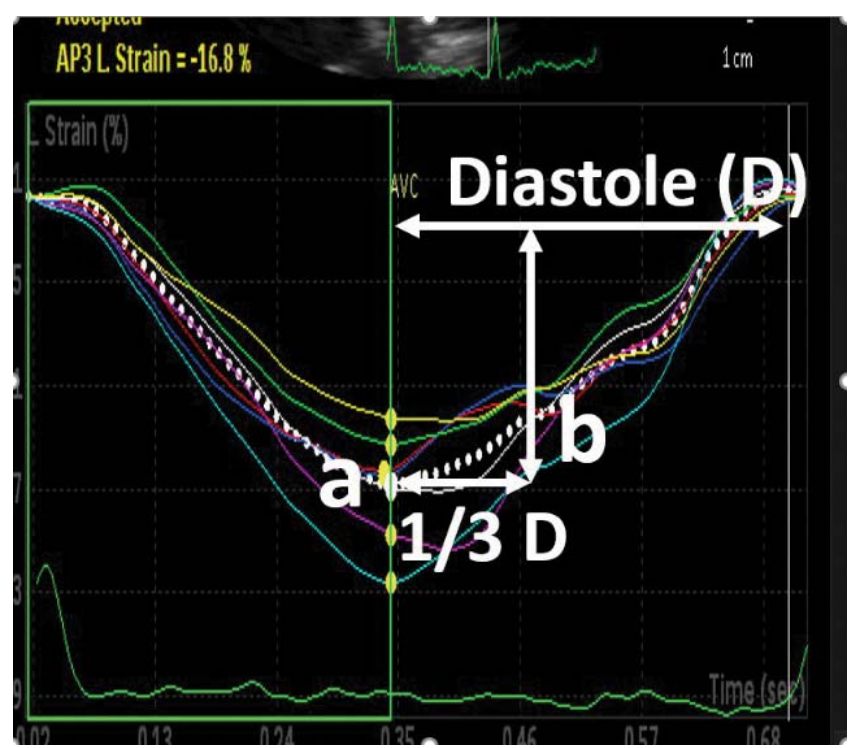

Figure I. Calculation of Global Longitudinal Strain Imaging Diastolic In$\operatorname{dex}(G L S I-D I)$ explained on strain curves. GLSI-DI was calculated with the formula: GLSI-DI=a-b/a where $a=$ average longitudinal strain at the closure of aortic valve and $b=$ =ongitudinal strain at $1 / 3$ of diastole, in 2-,3- Ind 4 chambers views.

but no significant obstructive lesions at present and 48 patients $(32.5 \%)$ were without obstructive artery disease (Table 3). Class of medication did not differ in the three subgroups $(p<0.05)$. Standard echocardiographic data showed no significant difference in the ejection fraction, left ventricular mass index and mitral E/A ratio, in the defined subgroups. Mean LVEF was different in subgroups but with no statistical significance (50\% in obstructive CHD vs $48 \%$ in non-obstructive $\mathrm{CHD}$ vs $54 \%$ in no $\mathrm{CHD}, \mathrm{p}=0.089$ ). Left atrial volu- me index, $e^{\prime}$ and $E / e^{\prime}$ were significantly different in obstructive $\mathrm{CHD}$ than in non-obstructive $\mathrm{CHD}$ or no CHD $(p<0.05)$.

\section{Strain analysis}

Mean left ventricle global longitudinal strain (LVGLS) was significantly lower (in absolute value) in angina vs control group $(-19.4 \%$ vs $-22 \%, p<0.00 I)$. In specified subgroups GLS was lower in absolute value in obstructive CHD than in non-obstructive CHD and no CHD (-16\% vs $-18 \%$ vs $-21 \%, p<0.05)$. Global SIDI was significantly lower in angina pectoris vs control group $(0.4 \mathrm{I}$ vs $0.69, \mathrm{p}<0.00 \mathrm{I})$. Average global SI-DI was significantly lower in the subgroup with obstructive coronary disease vs the other two subgroups $(0.32$ vs $0.4 \mathrm{I}$ and 0.46 respectively, $\mathrm{p}<0.05$ ) (Figure 2 and 3 ).

In univariate analysis lower global SI-DI was associated with a higher risk of coronary artery disease (Hazard Ratio 1.39, 95\% Confidence Interval 1.09I.49; $\mathrm{p}<0.05$ per $0.1 \%$ decrease).There was significant correlation between reduced global SI-DI and the presence of coronary artery disease $(r=-0,54$, $P<0.05)$, hypertension ( $r=-0.61, P<0.05)$, left ventricular hypertrophy $(r=-0.68, p<0.05)$, diastolic disfunction $(r=-0.69, p<0.05)$. Although LVGLS was also significantly different between subgroups $(p<0.05)$, we found a week correlation between global SI-DI and LVGLS (-0.39, $p=0.063)$. Global SI-DI lower than 0.5 had a good sensitivity (84\%) and negative predictive value $(71 \%)$ and a lower specificity $(40 \%)$ and positive predictive value $(52 \%)$ for detection of obstructive CAD.

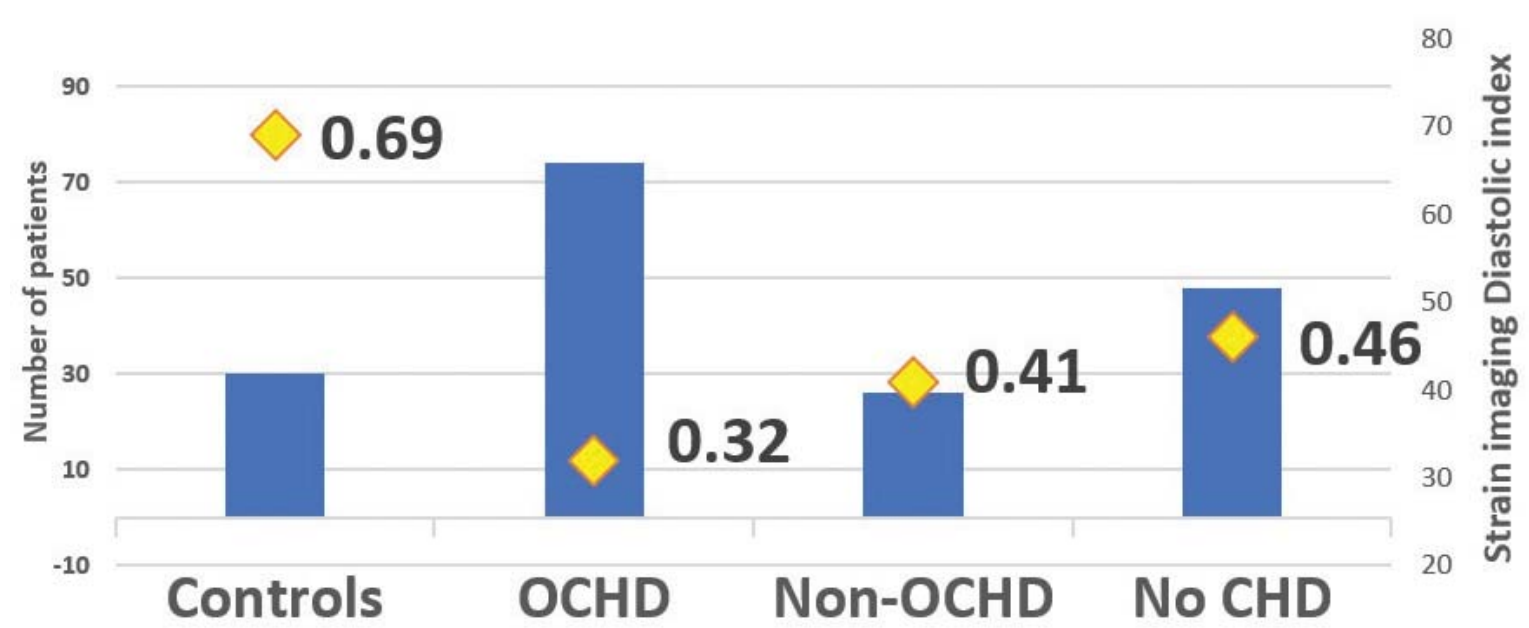

Figure 2. Mean value of longitudinal global strain imaging diastolic index (GLSI-DI) in healthy controls and subgroups of angina pectoris patients. $(\mathrm{OCHD}=$ obstructive coronary heart disease). GLSI-DI is significantly lower in OCHD vs healthy subjects $(0.32$ vs 0.69$)$, subgroup with non obstructive $\mathrm{CHD}(0.32$ vs $0.4 \mathrm{I})$ and vs subgroup without $\mathrm{CHD}(0.32$ vs 0.46$)$. 


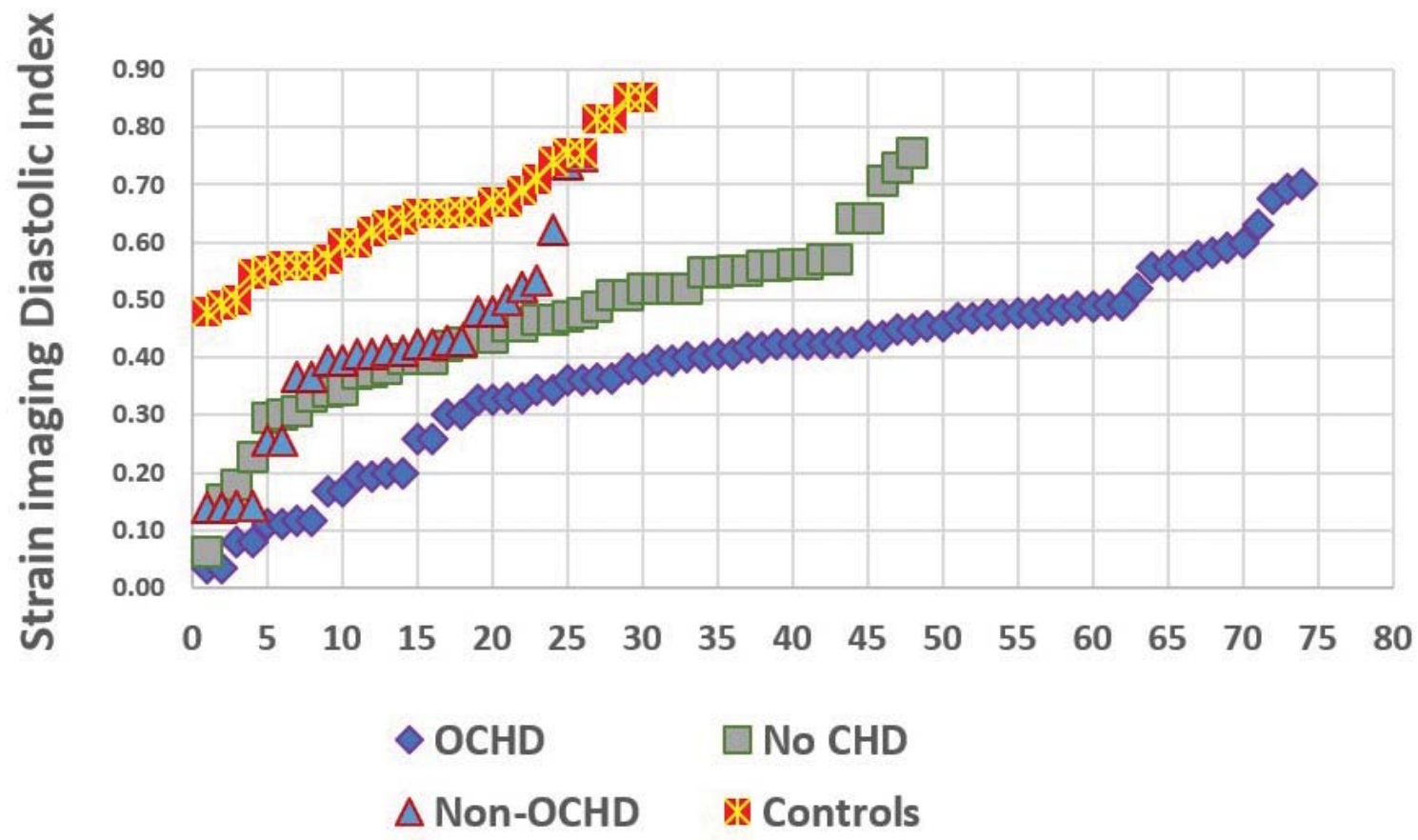

Figure 3. Graphic representation of the values of longitudinal strain imaging diastolic index (GLSI-DI) in each individual patient in healthy subjects (controls) and in specified subgroups defined after coronarography $(\mathrm{OCHD}=$ obstructive coronary heart disease subgroup, non-obstructive $\mathrm{CHD}$ subgroup=Non$\mathrm{OCHD}$ and without $\mathrm{CHD}$ subgroup=no $\mathrm{CHD}$ ).

\section{DISCUSSION}

In the current study we demonstrated the usefulness of a new parameter global SI-DI, assessed by 2D speckle tracking, in the diagnostic evaluation for obstructive coronary heart disease. The selected patients had a high probability of coronary artery disease 18 or have been previously revascularized. Systolic left ventricular function was normal or mildly reduced (EF $\geq$ $45 \%)$. Global SI-DI was significantly lower in selected group vs a healthy controls $(0.4 \mathrm{I}$ vs $0.69, \mathrm{p}<0.00 \mathrm{I})$. After coronarography we further divided the selected group in three subgroups: with more that $50 \%$ coronary obstruction in any major artery $(50 \%)$, with previous revascularisation but no significant obstructive lesions at present (17.5\%) and without obstructive artery disease. (32.5\%). Global SI-DI was significantly lower in each subgroup vs healthy patients $(p<0.001)$ and in the subgroup with obstructive coronary disease vs the other two subgroups ( 0.32 vs $0.4 \mathrm{I}$ and 0.46 respectively, $\mathrm{p}<0.05)$. Ejection fraction did not differ significantly between subgroups but LVGLS was lower (in absolute value) in obstructive CAD and in nonobstructive CAD vs no CAD $(p<0.05)$. We found a significant correlation between lower values of global
SI-DI and the presence of diastolic disfunction. Grade II and III diastolic disfunction, evaluated according to 2016 ASE/EACVI recommendations ${ }^{17}$ had a higher incidence in obstructive CAD group vs non obstructive CAD and no CAD ( $83 \%$ vs $50 \%$ vs $16 \%$ respectively) indicating that global SI-DI is also a parameter for assessing diastolic disfunction with high filling pressure. The weak correlation between global SI-DI and LVGLS could be explain by the fact that we used end systolic strain not peak systolic strain in the calculation formula and all our patients were a high cardiovascular risk group with other factors that could contribute to a modified LVGLS. Univariate analysis showed that lower global SI-DI was associated with a higher risk of coronary artery disease. The cut off value of 0.5 , selected in previous studies ${ }^{13-15}$, had in our study a good sensitivity (84\%) and negative predictive value (7I\%) thus it can be used to rule out significant coronary artery stenosis in rest echocardiography. The results of our study were not strong enough to demonstrate that rest global SI-DI is an independent parameter for prediction of obstructive CAD. This could be explained by the fact that global SI-DI evaluates alterations in early diastole that can appear in left ventricular 
hypertrophy, infiltrative myocardial disease or myocardial fibrosis. The positive predictive value at the cut off 0.5 was relatively low (52\%) but as shown in univariate analysis the lower the value the higher the probability of having obstructive CAD especially when used in appropriate clinical context (angina pectoris, positive stress test).

Previous studies demonstrated that diastolic left ventricular abnormalities are early signs of myocardial ischemia and persists longer than transient systolic disfunction $^{20-22}$. Ishiii demonstrated in 2009 that evaluation by $2 \mathrm{D}$ strain imaging of exercised-induced post-ischemic left ventricular relaxation or diastolic stunning is a reliable method for the detection of CAD. They proposed a new parameter, strain imaging segmental transverse diastolic index as a marker of regional acute ischemia (post-exercise) and proved that this parameter can improve diagnostic accuracy of stress echocardiography for the detection of significant CAD. Several studies showed that diastolic dysfunction persists longer, even 6 months after successful reperfusion in acute myocardial infarction ${ }^{23}$. Kimura ${ }^{13}$ showed that rest radial, longitudinal and transverse global SI-DI decreased significantly in severe stenosis segments and identified a cut off value of $50 \%$ for transverse SI-DI for predicting segments with severe stenosis with a sensitivity of 0.79 . Chiang ${ }^{14}$ demonstrated that global SI-DI corelated with NT-proBNP levels in asymptomatic hypertensive patients with preserved ejection fraction and concluded that global SI-DI might serve as a novel echocardiographic parameter for assessing diastolic function. Furthermore, global SI-DI may reflect elevated left ventricular filling pressure and its rapid change better than conventional diastolic parameters in patients with suspected CAD ${ }^{14}$.

2019 ESC guidelines of the diagnosis and management of chronic coronary syndromes recommends to use as initial test non-invasive functional imaging for myocardial ischemia or coronary CTA for the diagnosis of CAD in symptomatic patients in whom obstructive CAD cannot be excluded by clinical assessment ${ }^{19}$. In clinical practice exclusion of CAD by clinical evaluation is frequently difficult. We demonstrated that rest global SI-DI is an easy to measure parameter that could help in the assessment of obstructive coronary heart disease.

\section{CONCLUSIONS}

Global longitudinal strain diastolic index is significantly lower in patients with obstructive CAD and normal or mildly reduced ejection fraction compared with normal subjects. A cut off value lower than 0.5 selects patients with a higher probability of obstructive coronary heart disease.

\section{Study limitations}

This is a small study. The studied group of patients was selected regardless of the objective presence of ischemia and it was heterogenous group comprising patients with a high suspicion together with patients with already documented CAD. Another limitation was that we measured only longitudinal diastolic index and it is known that transverse and radial diastolic index are modified in CAD. The analysis was performed retrospectively so we had to exclude some segments with poor quality of image. The cut off point was not statistically demonstrated. Finally, we did not analyse SI-DI in relation with localisation and severity of coronary artery lesions.

\section{Conflict of interest: none declared.}

\section{References}

I. Patrick Collier, Dermot Phelan, Allan Klein. A test in Context: Myocardial Strain measured by Speckle Tracking Echocardiography. J Am Coll Cardiol. 2017; 69: 1043-56

2. Tanaka H, Kawai H, Tatsumi K, Kataoka T, Onishi T, Nose T, Mizoguchi T, Yokoyama M. Relationship between regional and global left ventricular systolic and diastolic function in patients with coronary artery disease assessed by strain rate imaging. Circ J 2007; 71:517-23

3. Liang HY, Cauduro S, pellikka P, Wang J, Urheim S, Yang EH, Rihal C, Belohlavek M, Khandheria B, Miller FA, Abraham TP. Usefulness of two - dimensional speckle strain for evaluation of left ventricular diastolic deformation in patients with coronary artery disease. Am J Cardiol 2006: 98: 158I-6

4. Azvedo Cf, Amado LC, Kraitchman DL, Gerber BL, Osman NF, Rochitte CE, Edvardsen T, Lima JA. Persistent diastolic dysfunction despite complete systolic functional recovery after rperfused acute myocardial infarction demonstrated by tagged magnetic resonance imagimg. Eur Heart J 2004; 25 : 1419-27

5. Ishii K, Suyama T, Imai M, Maenaka M, Yamanaka A, Makino Y, Seino $Y$, Shimada K, Yoshikawa J. Abnormal regional left systolic and diastolic function in patients with coronary artery disease undergoing percutaneous coronary intervention: clinical significance of postischemic diastolic stunning. J AmColl cardiol. 2009; 54: I589-97

6. Philip Brainin, Sofie Reumert Biering Sorensen, Rasmus Mogelvang, Peter Sogaard, jan Skov Jensen, Tor Biering- Sorensen. Postsystolic Shortening by Specckle Tracking Echocardiography Is an Independent Predictor of Cardiovascular Events and Mortality in the General Population J AM Heart Assoc. 2018;7: e 008367. DOI: 101 I6I/ JAHA. II 7008367

7. Koya Ozawa, Nobusada Funabashi, Takeshi Nishi, Masayuki Takahara, Hiroyuuki Takaoka, Yoshihide Fujimoto, Yoshio Kobayashi. Determination of quantitative post-systolic strain index threshold, assessed by two- dimensional speckle traking echocardiography for detection of myocardial ischemic segments confirmed on invasive fractional flow reserve. JACC20I5; 65: AI2I4

8. Ishii Katsuhisa, Imai Makoto, SuyamaTamaki, Motoyoshi Maenaka, Takahiro Nagai, Masaki Kawanami, Yutaka Seino. Exercise- induced post-ischemic left ventricular delayed relaxation or diastolic stunning: is it a reliable marker in detecting coronary artery disease? J Am Coll Cardiol. 2009; 53: 698-705 
9. Mads Ersbøll, Mads J Andersen, nana Valeur, Ulrik Mogensen, Yama Fahri, Jens Thune, Jacob E. Møller, Christian Hassager, Peter Søgaard, Lars Køber. Early diastolic strain rate in relation to systolic and diastolic function and prognosis in acute myocardial infarction study: a two-dimensional speckle tracking-study. European Heart Journal 2014;35:648-656

10. K. Ishii, K. Miwa, T. Sakurai. Motoyoshi Maenaka, MD,Takahiro Nagai, MD, Masaki Kawanami, Yutaka Seino. Detection of post-ischemic regional left ventricular delayed outward wall motion or diastolic stunning after exercise-induced ischemia in patients with stable effort angina by using color kinesis J Am Soc Echocardiogr, 2 I (2008), pp. 309-314

II. Masahiko Harada, Kyoko Hayashi, Yuichi Takarada, Hironori Hirai 2007 Mar;34(I):29-35. doi: I0.1007/s I0396-006-0I27-6

12. Lawrence A. Reduto, William J. Wickemeyer, James B Young, Leslie A. Del Ventura, John W. Reid, Donald H. Glaeser, Miguel A Quinones, Richard R. Miller. Left Ventricular Diastolic Performance At Rest and During Exercise in Patients With Coronary Artery Disease Assessment with First-pass Radionuclide Angiography. Circulation 63, No. 6, 198I.Downloaded from http://ahajournals.org by on June I, 2020

13. Koichi Kimura, Katsu Takenada, XiaoFang Pan, Aya Ebihara, Kansei Uno, Nobuaki Fukuda, Takahide Kohro, Hiroyuki Morita, Yutaka Yatomi, Ryozo Nagai. Prediction of coronary artery stenosis using strain imaging diastolic index at rest in patients with preserved ejection fraction. Journal of Cardiology (201I) 57, 3II-3I5

14. Shuo-Ju Chiang, Masao Daimon, Katsuhisa Ishii, Takayuki Kawata, Sakiko Miyazaki, Kuniaki Hirose, Ryoko Ichikawa, Katsumi Miyauchi, Mei-Hsiu Yeh, Nen-Chung Chang, Hiroyuki Daida. Assesment of Elevation of and Rapid Change in left Ventricular Filing Pressure Using a Novel Global Strain Imaging Diastolic Index . Circulation Journal $20 \mid 4 ; 78: 419-427$

15. Shuo-Ju Chiang, Masao Daimon, Katsuhisa Ishii, Sakiko Miyazaki, Yoko Koiso, Hiromasa Suzuki, Katsumi Miyauchi, Bei Yang, Mei-Hsiu Yeh, Betau Hwang, Hiroyuki Daida. A novel global strain diastolic index correlates with plasma NT-proBNP levels in asymptomatic hypertensive patients with preserved ventricular ejection fraction. J. echocardiogr.(2009);DOI 10.1007/s I 2574-0I 2-0 I22-4

16. Roberto M. Lang, Luigi P. Badano, Victor Mor-Avi, Jonathan Afilalo, Anderson Armstrong, Laura Ernande, Frank A. Flachskampf, Elyse Foster, Steven A. Goldstein, Tatiana Kuznetsova, Patrizio Lancellotti, Denisa Muraru, Michael H. Picard, Ernst R. Rietzschel, Lawrence Rudski, Kirk T. Spencer,Wendy Tsang, and Jens-Uwe Voigt. Recommendations for Cardiac Chamber Quantification by Echocardiogra- phy in Adults: An Update from the American Society of Echocardiography and the European Association of Cardiovascular Imaging. European Heart Journal - Cardiovascular Imaging (2015) 16, 233 27I doi:10.1093/ehjci/jev0I4

17. Sherif F. Nagueh, Otto A. Smiseth, Christopher P. Appleton, Benjamin F. Byrd,Hisham Dokainish, Thor Edvardsen, Frank A. Flachskampf, Thierry C. Gillebert, Allan L. Klein, Patrizio Lancellotti, Paolo Marino, Jae K. Oh, Bogdan Alexandru Popescu, and Alan D. Waggoner. Recommendations for the Evaluation of Left Ventricular Diastolic Function by Echocardiography: An Update from the American Society of Echocardiography and the European Association of Cardiovascular Imaging. European Heart Journal- Cardiovascular Imaging( 2016$) 17,1321-60$

18. Voigt J, Pedrizzetti G, Marwick $T$ et al; Definition for a common standard for $2 \mathrm{D}$ speckle tracking echocardiography: consensus document of the EACVI /ASE/ Industry Task Force to standardize deformation imaging European Heart Journal (2015); I6, I-I I

19. Juhani Knuuti, William Wijns, Antti Saraste Davide Capodanno, Emanuele Barbato, Christian Funck-Brentano, Eva Prescott, Robert F. Storey, Christi Deaton, Thomas Cuisset, Stefan Agewall, Kenneth Dickstein, Thor Edvardsen, Javier Escaned, Bernard J. Gersh, Pavel Svitil, Martine Gilard, David Hasdai, Robert Hatala, Felix Mahfoud, Josep Masip, Claudio Muneretto, Marco Valgimigli, Stephan Achenbach, Jeroen J. Bax . 2019 ESC Guidelines for the diagnosis and management of chronic coronary syndromes. European Heart Journal (2019) 00, I7I doi: 10.1093/eurheartj/ehz425

20. Bonow RO, Vitale DF, Bacharach SL, FrederickTM, Kent KM, Green MV. Adynchronous left ventricular regional function and impaired global diastolic filling in patients with coronary artery disease :reversal after coronary angioplasty. Circulation 1985;71:297-307

21. Wijns W, Serruys PW, Slager CJ. Effect of coronary occlusion during percutaneous transluminal angioplasty in humans on left ventricular chamber stiffness and regional diastolic pressure -radius relations. J Am Coll Cardioll 986; 7: 455-63

22. Mor-Avi V, Collins KA, Kocarz CE Shah M, Spencer KT, Lang RM. Detection of regional temporal abnormalities in left ventricular function during acute myocardial ischemia. Am J PhysiolHeart Circ Physiol 200 ; 280: HI770-8I

23. Neizel M, Korosoglou G, lossnitzer D, Kuhl H, Hoffmann R, Ocklenburg C, Giannitsis E, Ossman NF, Katus HA, Steen H. Impact of systolic and diastolic deformation indexes assessed by strain -encoded imaging to predict persistent severe myocardial dysfunction in patients after acute myocardial infarction at follow-up. J Am Coll Cardiol 2010;56:1056-62. 